\title{
A Prayer for Purification
}

\section{ברא}

\author{
Ellen van Wolde \\ Radboud University, Nijmegen, The Netherlands \\ e.vanwolde@ftr.ru.nl
}

\begin{abstract}
This article focuses on the pivotal role of verses 12-14 in Psalm 51. In v. 13 the speaker expresses the fear that due to his transgressions God's spirit of holiness will be taken away, because God does not tolerate impurity of any kind. For the impurity generated by the transgressions will be projected onto the sanctuary, which in this way will be defiled. Therefore, aligned with טהור לב in v. 13 in v. 12: purity is the sine qua non for God's holy spirit to stay and keep active in the midst of the Israelites. In this view, the impure world of words and deeds is the total from which the pure ones are to be separated. It is not the purity of the heart itself, but the process of purification that is expressed here, so that the pure heart remains, cleared of sins.
\end{abstract}

\section{Keywords}

Psalms - Psalm $5^{1}$ - purity - impurity - metaphorical patterns of sin - heart - the ברא verb

Would you ever dream of addressing God the Creator with the command: "create" (imperative of the verb ברא)? And if so, would you include yourself ("me") as the beneficiary of the divine act of creation? Yet, this is what readers and biblical scholars assume when they understand Ps 51:12 as "create for me a pure heart, o God". Would it not be contrary to the notion of creation, that is, to the act of making something (anything or everything) that did not exist before? And would it not be unique in its usage in the Hebrew Bible in its application to a human being only? Presumably, people have no difficulty with this problem since it has not been the topic of discussion. Yet, inspired by the recent dispute on the meaning of the verb ברא, I will present an analysis of 
Psalm 51:12-14 in the context of Psalm 51, describe the metaphors that figure in it, and discuss the position and meaning of the verb ברא in v. 12. In the end this will lead to a new understanding of these verses and of the verb ברא in v.12.

Although the composition of Psalm 51 may not necessarily reflect authorial unity, it does at least reflect a remarkable conceptual and composite unity at the editorial level. Only the latter level will be addressed in this article. ${ }^{1}$

Verses 12-14, a Bridge between the Two Main Parts of the Psalm $5^{1}$

The heading of Psalm $5^{1}$ in vv. 1-2 attributes the mizmor to David "after the prophet Nathan came to him, after he had come into Bathsheba", while the two final verses 20-21 refer to Zion and Jerusalem after they have been purified from their sins and conclude with: "then you [=God] will delight in righteous sacrifices and offerings ... on your altar". Together these opening and concluding verses represent the Psalm's framework and describe the king's and city's circumstances in which the embedded direct speeches enroll.

These direct speeches are presented in vv. 3-19 and show an apparent thematic disjunction between two parts, namely vv. 3-11 and vv. 12-19. ${ }^{2}$ In the former part, someone who is contending with sin expresses his own responsibility for what he has done and appeals to the deity for absolution, whereas in the latter part the topic shifts from personal penitential language to collective and cultic language. This shift from individual to community is noticeable in the contrast between the singular transgressor in vv. 5-8 and the plural transgressors in v. 15, and in the reference in vv. 18-19 to the sacrifices and the centralized

1 I would like to thank Lut Callaert, Ruti Vardi, Ed Greenstein and David Lambert for their readings and comments.

2 Many structures are proposed for this Psalm, but in general there is no disagreement on the framework. Most scholars make a distinction between vv. 3-11 and 12-19 as the main parts of the Psalm and distinguish vv. 12-14 as a smaller unit within the second part. See: P. Auffret, "Notes sur la structure littéraire de Psaume VI, 1-19," VT 26 (1976): 142-147; H. Spieckermann, "Psalmen und Psalter. Suchbewegungen des Forschens und Betens," in F. García Martínez and E. Noort (eds.), Perspectives in the Study of the Old Testament and Early Judaism. Festschrift A.S. van der Woude (vTs 73), Leiden: Brill 1998, 137-153; F.-L. Hossfeld and E. Zenger, Psalmen 51100 (HThK.AT), Freiburg im Breisgau: Herder 2000, 44-47; J.P. Fokkelman, Major Poems of the Hebrew Bible. Vol II: 85 Psalms and Job 4-14 (ssN vol. 41), Assen: Van Gorcum 2000, 164-169; C. Süssenbach, Der elohistische Psalter. Untersuchungen zu Komposition und Theologie von Ps 42-83 (Tübingen: Mohr Siebeck 2005), 88-89; H. Pfeiffer, “»Ein reines Herz schaffe mir, Gott!« Zum Verständnis des Menschen nach Ps 51", Zeitschrift für Theologie und Kirche 102 (2005): 293-311; P. van der Lugt, Cantos and Strophes in Biblical Poetry II, Psalms 42-89 (ots 57), Leiden/Boston: Brill; C. Abart, Lebensfreude und Gottesjubel. Studien zu psychisch erlebter Freude in den Psalmen (wMANT, vol. 142), Neukirchen-Vluyn: Neukirchener Verlag 2015, 175. 
altar in Jerusalem. An important difference between the two main parts of the Psalm is that the first part contains confessions of sinfulness and petitions for purification from sin in a "I-You" dialogic relationship, whereas the second part reverses it into a petition for salvation of others.

Less clear, however, is the exact border between these two parts: do the verses 12-14 belong to the individual prayer or to the collective part? Based on the division above, it would belong to the latter part. The appeal in v. 13 that God's holy spirit should not be withdrawn fits the corporate view, for the Hebrew Bible connects God's holiness with the temple, the priest and the king, or the people as whole rather than with ordinary individuals. The terms and do occur both in vv. 12-14 and in v. 19, which builds up a thematic line as well. On the other hand, the cleansing topic relates v. 12 to the previous prayers, as the term טהור לב in טהור shows. Most commentators take vv. 12-14 as the central unit, both structurally and thematically. Whether it should be considered a central unit or not remains to be seen, but it is clear that verses 12-14 function as a bridge between the two parts of the psalm that makes the transition possible from the individual confession to the corporate confessions and appeals.

\section{The Metaphorical Patterns of Sin and Kingship in Psalm $5^{1}$}

This famous psalm about sin, repentance, and forgiveness has a great evocative power which is partly based on its great number of metaphors. Some of them relate to the notion of sin.

In his fascinating monograph on the Patterns of Sin in the Hebrew Bible, Joseph Lam offers analyses of four metaphors that express the notions of sin in the Hebrew Bible: SIN IS A BURDEN, SIN IS AN ACCOUNT, SIN IS A PATH/ DIRECTION, and SIN IS A STAIN/IMPURITY. ${ }^{3}$ The metaphor of sin as "burden" draws from the shared human experience of the carrying of physical objects to provide a vocabulary for sin and its consequences in the Hebrew Bible; and the weight of sin, imagined as a burden carried by the sinner is frequently expressed by the verb נשא. The metaphor of sin as an "account" draws on the mundane language of record-keeping and depicts sin as entries in an individual's heavenly account, with forgiveness described as an act of "erasure" (the verb מחה); it often relates the concept of sin to the theological notion of God as judge and ruler. The metaphor of sin as a "path" or "direction" draws on spatial terms: walking on the path of sin, turning away from sin (expressed by the

3 J. Lam, Patterns of Sin in the Hebrew Bible. Metaphor, Culture, and the Making of a Religious Concept (Oxford: Oxford University Press), 2016. 
verb שוב), and notions of how the ways of the wicked and the righteous differ. Finally, the metaphor of sin as a "stain" or "impurity" involves the representation of sin as an object that intrudes the body it contacts, or as an impurity that disrupts the homogeneity of a pure state, and often involves usages of terms derived from the roots טהור טמא. In addition, Joseph Lam asks some important questions, namely: Is sin's proper locus in the individual or in the community? and: Is sin an act that is committed or a state into which one enters? Both questions and Lam's distinction in metaphors appear to be relevant for Psalm 51.

Ps 51:1-11 contain three nouns designating sins, iniquities or transgressions, most of them marked with pronominal suffixes in the first person singular, used in combination with verbs of blotting out, washing away, and purifying, which allows us to distinguish the following metaphors:

SIN IS AN ACCOUNT

RESTORATION IS BLOTTING OUT THE ACCOUNT

SIN IS A STAIN

RESTORATION IS WASHING AWAY THE STAIN

SIN IS AN IMPURITY

RESTORATION IS PURIFICATION

$\begin{aligned} \text { v. } & \text { v. } 3 b \\ \text { וכל־עונתי פבסני מעוני } & \text { v. } 4 a b \\ \text { תכחסני } & \text { v. 9b } \\ \text { ומחטאת יטהרני } & \text { v. 4b } \\ \text { תחטאני } & \text { v. 9a }\end{aligned}$

The metaphor of sin as an account assumes the notion of an external accountant or judge. It imagines God as a judge who sees all and keeps accurate accounts and whose acquittal is a blotting out of the written sins. Biblical usages of the verb מחה show a strong connection to writing: it denotes the erasure of writing of all kinds. ${ }^{4}$ Both biblical and inscriptional attestations that deal with writing point to the important connection between writing and memory. Because writing was associated with permanence, erasure of writing entails elimination of memory. ${ }^{5}$ This is discernible in contexts dealing with sin as well: the word combination of the verb מחה with a noun for sin is a conventionalized way of expressing the metaphorical erasing of written sins before God. ${ }^{6}$ The other two metaphors of sin, namely sin as stain and as impurity, share the idea of $\sin$ as an intrusion: they presume a thing that is outside of us, an

4 See Lam, Patterns of $\sin , 90-101$.

5 See, e.g., Exod 17:14; 32:32-33; Deut 9:14; 25:6; Ps 9:6; 69:29.

6 Cf. e.g. Ps 109:13-15. 
intrusion that does not belong. ${ }^{7}$ In the restoration of these sins the focus is on the stain or sin as the object of exclusion. On all these occasions in Ps 51:3-11, the metaphors of sin are located in the individual.

In vv. 15-21, on the other hand, words for sin, iniquity and transgression do not occur. Only once, in v. 15, reference is made to the transgressors and sinners in combination with "your ways" and "to return to you", which points at the following metaphor:

The metaphor of sin as a path is the result of mapping moral experience onto the realm of spatial movement; deviation involves metaphorically traversing a landscape. ${ }^{8}$ The forsaking of sinful actions is imagined as a change of direction: a return to the deity and to his road. Sin's locus in v. 15 is in the community.

The differences between the two parts of the Psalm are therefore visible in the difference in metaphorical patterns: in the first part of the Psalm the metaphors mark sin as an individual state, while the metaphor in v. 15 marks sin as a collective movement. The repair or restoration of the sinful state in vv. 3-11 is conceived as a change of state: the account is clean again, the stain is cleansed, the sin is forgiven. In v. 15 , however, restoration is conceived as a change in direction: they may return "to you". Thus the movement is conceived as a kind of home-coming: the absolved sinners will be allowed to live again in the presence of God. Together these metaphors of sin and repair in vv. 3-11 and v. 15 constitute a single metaphorical pattern of sin, a network that reflects a family of interrelated ideas on what sin is and on how one can face it and cope with it.

In addition to this metaphorical pattern, Psalm $5^{1}$ functions on the basis of two metonyms: THE KING STANDS FOR THE NATION (King David in the role of confessing and petitioning leader stands for the Jerusalemites) ${ }^{9}$ and THE

7 See Lam, Patterns of $\sin , 18$ o.

8 Ibid., 157-8.

9 The opening verses, vv. 1-2, refer to King David, and imply (a) that the speaking voice in this Psalm stands for David and (b) that David's process of transition from patient to agent [see the passage from "you will make $m e$ know" in v. 8 to " $I$ will teach the transgressors your ways" in v. 15; and the passage from "make $m e$ to hear joy and gladness" in v. 10 to "my tongue, my lips, my mouth will joyfully sing of your righteousness" in vv. 16-17] stands for the audience's passage from the recipient role to the agent role. 
SINNERS STAND FOR THE INHABITANTS OF JERUSALEM. Both are examples of pars-pro-toto metonyms. Whereas the former metonym is present on the background of the entire Psalm, the latter is introduced in vv. 15-21 in the transition from individuality to community and the transfer of the sin from the individual sinner (the king) to the people of Jerusalem.

Linked to these metonyms of human kingship are the metaphors that express the authority of God. Psalm 51 portrays God with such terms as שפט "judging", קדשף "your holiness", as the one capable of washing away stains, blotting away iniquities, and purifying sins, and, finally, as אדני 'my Lord'. In fact, the entire Psalm figures on the ground of the metaphors GOD IS JUDGE and GOD Is $\mathrm{KING}^{10}$ and the two are closely related because judging is the major activity of God as a king. ${ }^{11}$ Both metaphors entail the servants' loyalty to the king(s) and belong to the metaphorical pattern of polity. In this pattern, divine kingship is understood in terms of human kingship.

In the final verses of Psalm 51, vv. 17-21, the two metaphorical patterns of sin and kingship are transferred to the cultic domain. God is not portrayed anymore as the supreme judge, but as the deity. The speaking voice addresses him as "my Lord" and speaks of praise. Most prominently presented are the sacrifices and the conditions of their acceptance by the deity. Seen from the perspective of these final verses, the process of restoration from sin and purification of the heart are requisite to obtain the goal aimed for, namely that the inhabitants of Jerusalem will be permitted to sacrifice in the temple and may live in God's presence again.

\section{Analysis of the Syntactic Cohesion and Semantic Content of Verses 12-14}

The verses 12-14 with the collocations רב טהור "a pure heart", רוח נכון "a steadfast spirit”, רוח קדשך "the spirit of your holiness”, and רוח נדיבה "a willing spirit” play

10 Because of this metaphorical conceptualisation, the speaking voice could say "Against you, you only, I have sinned" (v. 6). Without it, this verse would have raised questions. For example, one could ask why the speaker does not say that he had sinned against Bathsheba or against Uriah. The might and power of God's kingship is also assumed in vv. 1ob and 19a: "you, God, have broken the bones", and "the broken spirit and the broken and contrite of heart" are conceived as the consequence of the divine punishment of the sinner.

11 Cf. M.Z. Brettler, God is King. Understanding an Israelite Metaphor. jsotss 76, Sheffield: Jsот Press 1989 . 
a pivotal role in Psalm 51. A syntactic and semantic analysis of these verses will elucidate their cohesion and content.

\begin{tabular}{|c|c|c|}
\hline ורוח נכון חדש בקרבי & לב טהור ברא־לי אלהים & 12 \\
\hline ורוח קדשך אל־תקח ממני & אל־תשליכני מלפניך & 13 \\
\hline ורוח נדיבה תסמכני & השיבה לי שששון ישעך & 14 \\
\hline
\end{tabular}

Syntactically and semantically, verses 12-14 form a tightly knitted unity. The fronted positions of the direct object in the clauses 12a, 12b, (not in v. 13a because of the negation), $13 \mathrm{~b}$, and $14 \mathrm{~b}$, distinguish these clauses clearly from the preceding and following verses, which have the regular word order with a verb in front position. This topicalization draws attention to the fronted direct objects רוח and רב לב טהוח in each of the three verses confirms their cohesion. Unique in Psalm $5^{1}$ is the usage of the indirect object 'ל 'to me' or 'for me' in v. 12a and v. 14a, which marks the first person in its semantic role of locative or benefactive. In the other clauses of vv.12-14, the first person is often collocated with a spatial preposition: "within me" (v. 12b), "me away from your face" (v. 13a), and "away from me" (v. 13b). Also the verbs seem to entail a notion of spatiality, as the verbs "casting out", "taking away", "returning to", and "upholding/sustaining" show.

Based on these features, the cohesion of vv. 12-14 can be described as follows. Verses 12 and 14 constitute the frame marked by repetitive use of the indirect object ל in v. 12a and v. 14a. They explicitly address the speaking voice as "to me". The clauses in vv. $12 \mathrm{~b}$ and $14 \mathrm{~b}$ regard the steadfastness or sustainability of the spirit "within me" or "upholding me" and elaborate on the addressed "me" position in v. 12a and v. 14a. Hence, the entire verses 12 and 14 profile "me" as an entity in itself. This stands in contrast to v. 13 which focuses on the relationship between "me" and "you", while using the most urgent terms to express this relationship: "(do not cast) me out from your face/presence" and "(do not take) away from me the spirit of your holiness". What is at stake here is the presence of "me" before God and the threat that God's holiness will be removed from "me". If that happens, no contact with the deity would be possible anymore. Thus v. 13 appears to be the heart of the unit vv. 12-14 and the crux of the entire Psalm, since it discloses what the ultimate threat of sin is: that the sinner will be cast out of the presence of God. 


\section{1 $\quad$ Verse 13}

Verse 13 consists of two verbal clauses, vv. 13a and 13b. The former clause contains (apart from the negation) two elements: the verb תשליכני and the preposition מלפניך. The Hiphil of שלך with God as subject and with the preposition "away from" appears to be used in the Hebrew Bible in one and the same "fixed" lexical construction: ${ }^{2}$

\begin{tabular}{|c|c|c|c|}
\hline Preposition & Direct object & $\begin{array}{l}\text { Verb } \\
\text { [subject YHWH/ } \\
\text { ELOнIM] }\end{array}$ & \\
\hline מעל־פניו & ه (=Israelites) & השליכ־ & $2 \operatorname{Kg} 13: 23$ \\
\hline 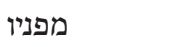 & ه (=offspring of Israel $)$ & השליכ־ & $2 \operatorname{Kg} 17: 20$ \\
\hline מעל פניו & אתם (=Jerusalem+ Judah) & השליכ־ & $2 \mathrm{Kg} \mathrm{24:20}$ \\
\hline \multirow[t]{2}{*}{ מעל־פני } & אתכם (=Israelites) & והשלכתי & Jer $7: 15 \cdot 15$ \\
\hline & את־כל־אחיכם את כל־זרע אפרים & והשלכתי & \\
\hline מעל פניו & אותם (=Jerusalem + Judah) & השליכ־ & Jer $52: 3$ \\
\hline מלפניך & ני (=me=speaking voice $)$ & השליכ־ & Ps $51: 13$ \\
\hline
\end{tabular}

In this conventional lexical construction the verb שלך imagines the deity's violent reaction as removal or expulsion away from him (expressed by מלפניך), more specifically, as a causative and volitional movement in a spatial domain; it is therefore a metaphor. In the other six occurrences of the construction the direct object is always a collective or plural term, allegedly with one exception, namely Ps 51:13. However, if this is indeed a fixed lexical chunk, then a sort of collectivity may also be implied in Ps 51:13. In that case, the individual speaker - who is the king - metonymically represents the nation. The implication of this latter option is that the fear expressed in v. 13a is not only that God expels the individual sinner from his presence, but also that God forces the leader of Jerusalem as representative of all Jerusalemites to leave the temple and that he will thus remove him (and the inhabitants of Jerusalem) from his holiness. This is exactly the threat that the next clause in v. 13b specifies:

12 For the study of conventional or fixed lexical constructions, see A.E. Goldberg, Constructions: A Construction grammar approach to argument structure (Chicago/London: The University of Chicago Press 1995), and A. Stefanowitsch and S. Gries, "Collostructions: Investigating the interaction of words and constructions", International Journal of Corpus Linguistics 8 (2003) 209-243. 
"please do not take your holiness away from me". At this moment God's holiness seems to be still nearby or approachable for the speaker. The point is that the speaker ('the king') expresses in v. 13b his fear that God's holiness will be taken away from him (and Jerusalem), whereas in v. 13a he was afraid that he (and they) would be sent away. The two clauses express, therefore, the same event of removal from a different perspective.

The almost unique word combination רוח קדשך in v. 13b (it occurs only here and in Isa 63:10-11) designates "the spirit of your holiness". An entire conceptual world resonates in the word קדש. ${ }^{13}$ In it, God, peoples, animals, places, and times are classified according to a category that is best typified in Lev 10:10: "You must distinguish between the sacred/holy (הטמש) and the profane/common (החל), between the impure (הטמא) and pure (הטהור)." Jacob Milgrom analyzed this compound category of [HOLY/COMMON] and [PURE/ IMPURE], showing that persons and objects are subject to four possible states: holy, common, pure, and impure. What is holy must be kept separate from what is not - for the sake of both domains — and in order to approach the holy, human beings must keep themselves separate from what is impure. Whereas the concepts of טהור an pan be aligned, impurity is a state opposed and detrimental to the holiness or sacredness. This sacredness or holiness is closely related to YнWн: He is the source of holiness and holiness is the extension of his nature.

The term רוח represents a spectrum of meanings ranging from wind and breath, to spirit and mind, and has as its basic meaning 'movement of air.'14 With regard to human beings the term is often used to indicate the driving force that acts in someone, while actions that lie beyond normal human nature

13 The here presented study of קדש is based on: M. Douglas, Purity and Danger (London: Routledge, 1966); E.L. Greenstein, "Biblical Law", in Back to the Sources: Reading the Classic Jewish Texts (ed. Barry W. Holtz), New York: Simon and Schuster 1984 (reprinted in 1992), 91-103; T. Frymer-Kensky, In the Wake of the Goddesses: Women, Culture, and Biblical Transformation of Pagan Myth. (New York: Free Press, 1992); J. Milgrom, Leviticus 1-16 (Anchor Bible vol. 3, pp. 704-36; 763-67, 986-1004), Leviticus 17-22 (Anchor Bible, vol. 3A, pp. 1594-1725), New York: Doubleday 1991 and 2000; J. Joosten, People and Land in the Holiness Code: An Exegetical Study of the Ideational Framework of the Law in Leviticus 17-26 (vTs 67), Leiden: Brill 1996; J. Naudé, “קדש", in NidotTE vol. 3 (1996), 877887; E.J. van Wolde, Reframing Biblical Studies. When Language and Text Meet Culture, Cognition, and Context (Winona Lake (IN): Eisenbrauns 20o9), 206-268.

14 M. Dreytza, Der theologische Gebrauch von Ruah im Alten Testament. Eine wort- und satzsemantische Studie (Monographien und Studienbücher 358), Giessen/Basel: Brunnen 19901 1992² , 38; H. Schlüngel-Straumann, Ruah bewegt die Welt, Stuttgart 1992; A. Krüger, Das Lob des Schöpfers. Studien zu Sprache, Motivik und Theologie von Psalm 104 (WMANT 124), Neukirchen: Neukirchener Verlag, 2010. 
are usually attributed to God and his רוח which then represents a presence or a moving force that drives someone to act in certain ways. ${ }^{15}$ Therefore, the word combination expresses God's holiness as an active presence that pervades everything and as a life force that keeps everything going. Because the spirit of God's holiness is exclusively related to him, God can also take it away again. In v. 13, the speaker fears that due to his transgressions God will decide to stay no longer in midst of the Israelites. For the impurity generated will be projected onto the sanctuary, which in this way will be defiled. The final effect will be the withdrawal of divinity from his earthly dwelling, for his holiness cannot co-exist with impurity. Therefore, aligned with רוח קדשך in v. 13 is לב טהור in v. 12: purity is the sine qua non for God's spirit to stay present and to keep active in the midst of the Israelites.

\subsection{Verse 12: Purity}

The word combination לב טהור in v. 12a is unique; it occurs nowhere else in the Hebrew Bible. The two terms will subsequently be analysed. To understand the notion of purity better we start with an analysis of two key passages: Lev 20: 22-26 and Num 35:33-34.

Lev 20: 22-26 is generally considered to be the key passage on purity and defilement in ancient Israel. YHWH addresses the Israelites saying "I give you the land to possess, I am YHWH your God, I set you apart from other people. So you shall set apart the pure beast from the impure, the impure bird from the pure." And he concludes "You shall be holy to me for I YHWH am holy I have set you apart from other peoples to be mine." Thus YHWH expresses his intention that not the impure other peoples are to be set apart, but the pure one. ${ }^{16}$ In his commentary, Jacob Milgrom explains that the forbidden animals are analogous to the surrounding nations, whereas the clean or pure animals represent the Israelites. The large number of other people in comparison to the minority group Israel functions as a simile of the large number of impure animals in comparison to the small number of pure animals. And he concludes: "The separation of Israel from the nations is a sine qua non for the maintenance of order within the human world (...). Indeed separation is inherent in holiness. The word qādôs ' holy' means both 'separate from' and 'separate to."'17 The conceptual framework in which the world is construed in such a way that

15 R.A. diVito, "Old Testament Anthropology and the Construction of Personal identity", $C B Q$ 61 (1999) 217-38.

16 The same applies to pure animals that are to be set apart from the impure ones. Cf. E.L. Greenstein, "The Dietary Laws" in Etz Hayim. Study Companion (eds. J. Blumenthal and J.L. Liss), Jewish Publication Society 2005, 247-256.

17 Milgrom, Leviticus 17-22 (vol. 3A): 1761-2. 
the [IMPURE/UNCLEAN] and the [HOLY/PURE] are conceived of as mutually antagonistic and irreconcilable, is applied in Lev 20: 22-26 to two cognitive domains: food and its region of unclean animals, and Israel's relations to non-Israelite peoples. In both domains, purity/impurity profiles its meaning on the base of separation.

Numbers 35 is another enlightening text in this respect, in which the close link between land and deity is crucial. The land should be respected, because it is YHWH's dwelling place (v. 34c). In the case of an intentional murder or accidental homicide, the blood that has been removed from a live body is a pollutant. Because of the land's close relationship to the deity, the polluted environment would entail the contamination of YHWH's place of residence by impurity. The transfer of impurity from a single origin and its spread over the entire Israelite community is the actual threat. Murder infects the whole Jerusalemite community and threatens their blessed existence in YHWH's presence.

Based on these and many other texts that deal with adultery, idolatry, bloodshed, disease, child sacrifices etc., "purity" appears to be the tip of an encyclopaedic iceberg. It figures in a conceptual universe in which the perceived and experienced world is organised according to the compound category of [PURE/IMPURE] and [HOLY/COMMON] that enables the Israelites to create order and to signify. As Milgrom shows, there is an overlap but not an identification between purity and holiness, they figure as terms that are not directly but indirectly related. ${ }^{18}$ Greenstein specifies it further. ${ }^{19}$ In his scheme, purity is environmental, whereas holiness is specifically related to the deity. In both views, the cognitive domains of Israel, the peoples, the land, and the deity YHWH play continuously in the background. It profiles its meaning on the inherently included base of [REQUIRED SEPARATION]. It transpires that the mental image evoked by purity significantly depends on this base structure.

Psalm $5^{1}$ figures in the same conceptual universe. The notion of purity is v. 12 is not that the impure entity is to be set apart, but the pure one. In fact, the impure world is the total from which the pure ones are to be separated. This pure entity is called לב.

\section{$3 \cdot 3$}

\section{Verse 12: Heart}

In the classical twentieth century approach, represented most prominently by Wolff and Fabry, scholars concentrated on the study of the separate

\footnotetext{
18 Milgrom, Leviticus 1-16 (1991), 722-732.

19 E.L. Greenstein, "Biblical Law", (see note 13).
} 
anthropological words, such as נפש ,רוח ,בשר, לב , to understand their meaning. ${ }^{20}$ One of the conclusions of this research was that לבלביב in the Hebrew Bible is not simply a bodily organ (in a physiological or metaphorical sense), but represents the center of the human being: לב stands for the inner world in which all kind of thoughts, feelings, emotions, wishes, reflections are located. At the same time it was noticed that these faculties were not linked to the heart alone, but also to נפש , "vital power", כבד "liver", and that often these notions are interchangeable. ${ }^{21}$ This classical approach became criticised as "reduction of anthropology to semantics", that is to say, as an approach in which one studied words as if their meaning coincides with conceptual meaning. ${ }^{22}$ However, the conceptual meaning of words is intimately linked to the way the world is viewed and structured in a culture, to the way the human body is understood, and to views on the individual, the family, the society, the deity/deities and their relationships. New questions arose, such as: should not the study of לב be embedded in the wider discussion of the self and is it still true that the heart stands for the inner self? If one adheres to the view that ancient Israelites thought themselves in terms of collectivity and heteronomy and not in terms of individuality and autonomy, ${ }^{23}$ does this

20 W.H. Schmidt, Anthropologische Begriffe im Alten Testament. Anmerkungen zum hebräischen Denken (EvTh 24 (1964) 374-388); H.W. Wolff, Anthropologie des Alten Testaments (Gütersloh: Gütersloher Verlagshaus 1973 ${ }^{1}, 2002^{7}$ ), English translation: Anthropology of the Old Testament, Philadelphia: Fortress; F. Stolz, לב, THAT I (1975²) 861-867; R. Lauha, Psychophysischer Sprachgebrauch im Alten Testament: Eine struktur-semantische Analyse von "lev", "nefesh" und "ruah" (Annales Academiae Scientiarum Fennicae, Dissertationes Humanarum Litterarum 35; Helsinki 1983); H.-J. Fabry, לב, ThWAT 4 (1984) 413-451 (English translation тDот vol. 7, 399-437); B. Janowski, "Mensch" in RGG4 Bd.V (2002) 1057-58; S. Schroer \& T. Staubli, Die Körpersymbolik der Bibel (Gütersloh: Gütersloher Verlagshaus $\left.2005^{2}\right)$; T. Krüger, "Das "Herz" in der alttestamentlichen Anthropologie" in A. Wagner (hrsg.), Anthropologische Aufbrüche. Alttestamentliche und interdisziplinäre Zugänge zur historischen Anthropologie (Göttingen: Vandenhoeck \& Ruprecht 2009), 103-118.

21 Wolff, Anthropologie, 29; Lauha, Psychophysischer, 148; Dreytza, Der theologische Gebrauch, 148 .

22 See, among others, J. Barr, The Semantics of Biblical Language (Oxford: OUP 1961), and A. Wagner, "Wider die Reduktion des Lebendigen. Über das Verhältnis der sog. anthropologischen Grundbegriffe und die Unmöglichkeit, mit ihnen die alttestamentliche Menschenvorstellung zu fassen", in A. Wagner (hrsg.), Anthropologische Aufbrüche. Alttestamentliche und interdisziplinäre Zugänge zur historischen Anthropologie, (Göttingen: Vandenhoeck \& Ruprecht 2009), 183-201.

23 A.C. Hagedoorn, Between Moses and Plato: Individual and Society in Deuteronomy and Ancient Greek Law (FRLANT 204, Göttingen 2004) offers a survey of recent literature on group-embedded / group-oriented or collectivist views. 
affect their view of the heart? Three recent studies have dealt with these kinds of questions. ${ }^{24}$

Jan Dietrich observes that in many texts in the Hebrew Bible לב often is combined with verbs of hearing, speaking, impression of the senses, and experiences, and that the heart is inspired by the outside world rather than by the inner world. ${ }^{25}$ Another difference between the ancient and modern view of the heart becomes visible as well. Whereas in modern culture the "inner heart" is judged positively, in the Hebrew Bible the "inner heart" is evaluated negatively, while the heart that is guided by the world outside is judged good and social. ${ }^{26}$ It appears that the term לב is used in such a way that it does not get a positive connotation when linked to the inner self, but is only evaluated positively when it relates the human being to the world outside oneself. This is why in wisdom and prophetic literature humans are called upon not to withdraw themselves into their inner world as behind walls, but to open their heart and to enter into contact with the world outside.

In another recent study of לב, David Lambert comes to similar conclusions, although he starts his analysis from a different perspective. He criticizes "the broad scale translation of biblical words into the terms of individual subjectivity",27 and wishes to look behind the modern idealist view of the subjective psyche. Inspired by Vološinov's conceptualization of the "subjective psyche" as a "borderline", defining the encounter "between the organism and the outside world," Lambert makes a renewed study of לב, and presents a series

24 J. Dietrich, "Individualität im Alten Testament, Alten Ägypten und Alten Orient", in A. Berlejung, J. Dietrich, J.F. Quack (eds.), Menschenbilder und Korperkonzepte im Alten Israel, in Ägypten und im Alten Orient (Orientalische Religionen in der Antike 9, Tübingen: Mohr-Siebeck 2012), 77-96; D. Lambert, "Refreshing Philology: James Barr, Supersessionism, and the State of Biblical Words", Biblical Interpretation 24 (2016) 332-356; E. Greenstein, "The Heart as an Organ of Speech in Biblical Hebrew", paper presented at the SBL-meeting, Boston 2017; to be published as "The Heart as an Organ of Speech in Biblical Hebrew" in Festschrift R.C. Steiner (ed. A. Koller), Yeshiva Univ. Press, Jerusalem 2019 .

25 Dietrich, Individualität, 83: "Das Herz des Menschen ist hier im Wesentlichen nicht innen-, sondern außengeleitet. (...) Allerdings verhält es sich keineswegs so, dass das Herz im Alten Testament den Bereich der Innerlichkeit vollständig ausschließen würde."

26 Dietrich, Individualität, 84: "Der entscheidende Unterschied zur Moderne besteht darin, dass dieses "innerlichte Herz" keineswegs positiv gesehen, sondern in einen negativ konnotierten Gegensatz zum außengeleiteten Herzen gesetzt wird. Das außengeleitete Herz ist das gute und soziale, das innengeleitete das egoistische, das Täuschung, Treubruch und Heuchelei ersinnt."

27 Lambert, "Refreshing," 348. 
of examples of לב that mark the boundaries of the self. ${ }^{28}$ In his more extensive analysis of Deut 6:5, he asks: "What does it mean that "You shall love YHWH your God with all your heart and with all your soul and with all your might" (Deut 6:5)?" What is at stake in this passage clearly involves the performance of commandments. In fact, Deut 6:5 describes a YHWH loyalist as someone who is consistently present to YHWH and fully committed to the service of the deity. Lambert concludes that this verse may not describe the quality of an "inner life" at all, not something that exists inside or proceeds from an individual, but points to a social relationship, a proximity between two beings, an interrelation of borderlines. Based on his analysis of these and other texts, Lambert proposes to consider "heart" as "a rhetorical mode for describing a being in relation to outside forces". 29

Most recently, Ed Greenstein presented an analysis of the heart" (לב ,לבב) as an organ of speech. ${ }^{30}$ In the Hebrew Bible in a number of passages, speech is attributed to the "heart", using a number of verbs that denote vocalization. In these passages "heart" (לב) is a physical organ in the chest and Greenstein dismisses therefore the proposal made by Lambert, according to whom the biblical "heart" (לב) is not "a discrete entity" but "a rhetorical mode" that serves as a function rather than a physical location. ${ }^{31}$ Of this heart it is unambiguously said to produce speech, and not only thought. And Greenstein makes a clear distinction between the heart as the organ of speech and the heart as the addressee of speech ("to speak to one's heart / to oneself"). In the former the heart is the subject or agent of speech, whereas in the latter the heart has an adverbial relationship to a verb of speaking and the verbum dicendi is predicated of a subject who speaks.

28 Lambert discusses Exod 9:34 ("hardening of the heart"); Deut 6:5 ("you shall love YHWH your God with all your heart"); 17:20 ("elevate his heart above his brothers"); Isa. 1:5-6 ("every heart is sick"); 14:13 ("once you spoke in your heart") and asks: "What does it mean for the 'heart' to be 'sick', to be 'haughty', to be 'hardened'? Are these statements about the nature of feelings, character, and will, what is in our 'hearts', or signs depicting the relations that pertain between our beings and the outside world?" Lambert, "Refreshing," 343 .

29 Ibid., 346.

$30 \quad$ Greenstein, "The Heart as an Organ of Speech" (see note 35).

31 Greenstein, "The Heart as an Organ of Speech": "When the prophet describes the "heart" within a rib-cage (Hos 13:8) and a maiden asks to be placed over her beloved's "heart" or bosom like a carved seal (Song 8:6), when the arrow shot by Jehu entered Jehoram in the back and protruded through the heart, in the chest (2 Kings 9:24), when the priest wears the breastplate over his heart, located in the thorax (Exod 28:29-30), when Jeremiah feels a throbbing (המה) within the "walls of my heart" (Jer 4:19), the heart clearly is a very particular organ within the chest cavity.' 
The recent expositions by Dietrich, Lambert and Greenstein account for aspects in the ancient conceptualization of the heart that have been neglected for a long time. Influenced by modern idealist views and maybe also by Christian views of individual subjectivity, the heart was either seen as an organ or as a (metaphorical) state, but always limited to the inner life of an individual. Their studies demonstrate that the heart is closely related to outside world, that it represents a contact point or borderline where the outside and the inside world meet. ${ }^{32}$ The heart thus figures both as the access point of impressions and insights inspired by the outside world and as the point of departure of actions and speech. ${ }^{33}$ This is visible, for example, in the prayer of Solomon in 1 Kgs 3:9 where the king petitions God to "give your servant a listening heart to judge your people, to distinguish between good and bad", and in Ps 86:11 "let my heart be undivided to fear your name". The aim of the improvement of the heart is to act as a better king or judge, or to pay complete attention to and fear God. Thus we may conclude that the heart is conceived as the physical organ in the chest that functions as the contact point between the outside and inside world, where experiences, emotions and thoughts amalgamate and spring into words and language.

\subsection{The Purification of the Heart and the Verb 12 in V. 12 a}

Scholars such as Mary Douglas, Jacob Milgrom and Edward Greenstein (and many others) have shown that the conceptual link between God's holiness and human purity is based on separation: pure entities must be kept apart from impure entities or an impure environment, and this may regard pure animals that have to be separated from impure animals, or pure Israelites that have to stay away from infectious and impure non-Israelites. All this is necessary because God's holiness would be polluted by an impure environment. He can, therefore, not tolerate impure behaviour of any kind. This is also expressed in Ps 51:12-13. God's holiness in v. 13 and the heart's purity in v. 12 are closely linked to each other. The collocation לב טהור "a pure heart" designates the heart as

$32 \quad$ It is exemplified in Prov 23:33, "Your eyes will see strange sights; Your heart will speak distorted things".

33 Cf. Dietrich, "Individualität," 87: "Vorherrschend ist allerdings nicht das Ideal, dass sich der Mensch in seine Innerlichkeit wie in ein Schutzwall zurückzieht, sondern vielmehr diejenige des immer schon auf die Außenwelt bezogenen "innengeleiteten Menschen." Der hebräische Mensch als vornehmlich relationales Wesen soll sein Vernunft (לב) nicht etwa dazu nutzen, um sich selbst allein zu sein (secum esse) und sich in einer Art Selbstgespräch (secum loqui) den tiefen der eigenen Innerlichkeit zu widmen, sonder um von ihr ausgehend in der Welt entsprechende Worte und Taten folgen zu lassen." 
the contact point with the outside world that is separated from or is kept apart from staining impurities, be they experiences, thoughts or deeds.

It is not the purity of the heart itself, but the process of purification that is expressed here, as the verbal clause לב טהור ברא-לי shows. In this clause the verb marks the act of separation or purification, so that "the ore remains" (as in metal refining), that is, the heart purified or cleared of sins. ${ }^{34}$ In an earlier article on the verb ברא, in which the pros and cons of the meaning "to create" or "to separate" were discussed, I expressed a preference for the latter meaning. ${ }^{35}$ This view is confirmed by the present study of Psalm 51:12, since it does not point to the creation of the heart, but to the purification of the heart. The beneficiary of this act of purification is "me", the supplicant. He asks the deity to attribute to him a heart that is guided by the world outside yet set apart from previously accumulated impurities and sins. By placing the direct object in front position it receives full emphasis, not as the state of an individual subject, but as the relational state of proximity that allows the speaker (and the people whom he represents) to remain in the presence of God. Only then he (and they) can remain committed to the worship of the deity.

\subsection{Verse 12b: The Renewal of a Steadfast Mind}

In addition to v. 12a, which regards the contact point's purification to make a relationship with the deity possible again, the next clause in v. 12b, ורוח נכון חדש בקרבי , reflects the supplicant's steadfastness. Similar to v. 12a, the fronted direct object רוח נכון receives full emphasis: it occurs only here in Psalm $5^{1}$ and nowhere else in the Hebrew Bible and is, therefore, as unique as the word combination נלב טהור in v. 12a. The adjective נכון (a Niphal participle of כון expresses steadfastness. It is used in the Hebrew Bible to express the firmness of solid constructions, such as "the world" (תבל-the earth as a material disk) and "YHWH's throne" (Ps 93:1-2 and 96:10), "the mountain of YHWH's house" ("shall stand firm above the mountains" in Isa 2:2 and Mich 4:1), "the pillars of the temple" (Judg 16:26.29), and "the house" or "the throne" of the king (2 Sam 7:26; $1 \mathrm{Kg}$ 2:45.46; 1 Chron 17:14.24). In all these instances a material base structure

34 Because v. 12a is a verbal clause, in which the verb ברא expresses an action and the adjective טהור designates the state or quality of the heart, the translation "make/build/create a purified heart" has to be dismissed. The translation of טהור as "purified" would entail the action of purification. However, the adjective does not denote an action but quality of the heart. Only together, the verb ברא and the heart's state as a "pure heart" express the action or temporal process of purification.

35 See E.J. van Wolde, "Separation and Creation in Genesis 1 and Psalm 104. A Continuation of the Discussion of the verb ברא, VT 67 (2017) 611-647, also for an extensive bibliography. 
is imagined as a firm and everlasting construction. This concrete meaning is then expanded metaphorically to describe the firmness of the heart (Ps 57:8; 78:37; 112:7), of knowledge (1 Sam 23:23; 26:4; Job 15:23) and of words (Gen 41:32; Deut 13:15). On all these occasions it marks not the enduring state as such, but the quality or capacity of remaining firm. Therefore, the רוח נכון the supplicant asks for in v. $12 \mathrm{~b}$ is not a temporal state of mind, but an enduring spirit or force that can uphold him against future attacks of impurities or sins. The verb חדש (Pi'el), "to renew" or "repair", does indeed mark this newly construed condition and includes the connotation that this spirit in the breast of the supplicant had been sinful and less firm in the past. Thus v. 12b appears to be the logical consequence of v. 12a: once the heart has been purified, the supplicant needs a steadfast spirit, a force that will keep on driving and protecting him with firmness in future.

In sum, v. 12a and v. 12b together contain a prayer for purification of the heart and for a renewal of a steadfast spirit. These two events reflect the condition prerequisite for the supplication in v. 13. Only after the prayer in v. 12 has been fulfilled, the supplicant can utter his plea in v. 13 "do not chase me away from your presence and do not take your holiness away from me". Therefore, the purification of the heart and the renewal of a steadfast mind are the sine qua nons for God's holy spirit to stay and keep active in the petitioner, and indirectly through this representative leader, may stay active in the midst of the Israelites. In this reading, the alignment of רוח קדשך in v. 13 and לב טהור in v. 12 stands at the heart of the psalm.

\subsection{Verse 14}

With the request to let joy return to the supplicant and to let a willing spirit sustain him, verse 14 describes the consequence of vv. 12-13. The rhetorical figure is clear: the petitioner acts as if the process of appeal has been concluded with forgiveness. It is this persuasive rhetoric of the transition from a state of sinfulness to a renewed and purified proximity relation with the deity that allows him to speak of joy and proves that the process of appeal is successful and the sinner saved.

In v. 14b for the third time the term רוח occurs. As in v. 12b it relates to the human mind or vital force, not that of the deity (only in v. 13b). The clausal construction in v. 14 b is ambiguous, because the verb תסמכני can either be read as a third person feminine singular with "the spirit" as subject, or as a second person masculine singular with "you" (God) as subject. In the latter case the clause fits the general pattern of the psalm in which God is the acting subject and seems therefore more likely. The supplicant asks for a רוח נדיבה, 
that is, a willing, voluntary, or generous spirit. ${ }^{36}$ In general the verb סמך refers to support or strengthening provided; it frequently has God as the subject of the verb, especially when he is said to uphold the righteous and bowed down (Ps 37:17.24; 119:116; 145:14). ${ }^{37}$ The word combination in v. 14b describe the two sides of a future process in which the sinner, who has been cleared from sin and is joyful because of his salvation, is on the one hand willing or acting voluntarily himself, and on the other hand in need of God's continuous support. This support should uphold and sustain him in future difficult times.

Immediately following this crucial section, the other people who are also characterised as sinners and transgressors, are addressed in vv. 15-17. The speaker ("the king") has taken up his role as a leader again, teaching the other transgressors and sinners. Through his words they will learn what he has learned and thus they too can be liberated from their sins. Only after this has taken place, will God accept their sacrifices.

So far we have not discussed the actual content of the sinner's iniquity. In v. 1 reference is made to David "after he went into Batsheba", so the sin implied is adultery. In the book of 1 Samuel this adultery is followed by David's order to his commander-in-chief to have Uriah, Bathsheba's husband, killed. The question arises whether Psalm $5^{1}$ makes reference to this command to murder or to bloodshed as well? I think so, because v. 16 reads: "Save me from blood iniquity (דמים) o God, the God of my salvation." The word דם "blood" designates not just the bodily liquid but entails the notion of life of human being or animal. Used in singular or plural it may also denote bloodshed or blood as shed by violence and in the plural it often denotes bloodguilt; the collocation with the preposition מה מילני makes the last option in v. 16 most plausible. The word order of v. 16, with aהלים at the end of the verbal phrase in its function of vocative is remarkably similar to v. 12 . In v. 16, the deity is supplicated to take "me away from" the bloodguilt. The conceptual link between bloodshed and purity looms at the background, because it threatens the purity

36 The dictionaries (BDB, DCH, NIDOTTE) describe the term נדיב as an inner motivation of persons, the attitude of freewill, willingness or generosity that moves a person to act. In the light of the recent theories and studies of the self a further analysis of this notion is needed.

A.M. Harman, סמך in NIDOTTE, vol. 3, 270-271. 
of the land and the place where YHWH is dwelling. To remove this guilt would purify both the murderer and the land. To purify the heart would then include notions of reparation both to the individual sinner, the king and the land and community that lives on it in the presence of their lord.

Again rhetoric plays an important role. Three times the deity is directly addressed: in v. 16 these are called אלהי תשועתי and and and culminate in the direct deferential language used in v. 17, אלה "my lord". It marks the transition from petition for one's own salvation to the supplicant who persuades others with his mouth and lips to praise the Lord.

In my discussion of the final verses 18-21, I will concentrate on the metaphorical pattern present at the background of these verses. The use of the words and in v. 19 points back to the pure heart and steadfast spirit in vv. 12-14. However, here, in v. 19 they are said to be broken and crushed: רוח נשבר and לב־נשבר ונדכה The effect of sin on people is described as a state of brokenness. It draws from the human experience of the breaking and crushing of physical objects when they are pressed very hard so that their shape is destroyed, broken or ground into powder. In this metaphorical image people in dire straits are compared to material objects in a state of destruction and beyond repair. Nevertheless, v. 19b states that the deity לא תבזה "will not despise" the broken and crushed heart. Usually when something is destroyed or broken, you throw it away, because it is of no more use. The idea expressed here, is the opposite: although the heart and mind are 'crashed', God will not reject them. He will repair and reconstruct them.

Let us return to the notion of לב discussed above. We saw that the "heart" in ancient Israel is conceived as a contact point with the outside world. In the metaphorical image of v. $19 \mathrm{~b}$ the heart is materialised: it is imagined as the material access point and departure point broken down or crushed under extreme pressure. In these circumstances the heart cannot function anymore as a meeting point between the outside world and inside world. However, the expectation that the deity will not despise it, but will still value and foster it, creates a hope for restoration. In the light of this metaphor, v. $20 \mathrm{~b}$ that speaks of "the rebuilding of the walls of Jerusalem", makes sense. It forms another element in the metaphorical pattern of sin and destruction/reconstruction. 
SPIRIT AND HEART ARE MATERIAL OBJECTS

SIN BRINGS THE HEART AND MIND INTO STATES

OF DESTRUCTION AND BROKENNESS

FORGIVENESS IS RECONSTRUCTION /

REBUILDING OF THE CITY WALLS

\author{
v. 19a \\ v. 19b \\ v. 2ob
}

Thus everything falls into place: the metaphor in which the effect of sin is described in terms of states of destruction and brokenness and the metaphor in which forgiveness is described in terms of reconstruction and rebuilding build into one coherent metaphorical pattern. The building of the walls of Jerusalem has surprised many commentators on Psalm 51. Yet, it can be understood as an element of this larger metaphorical pattern. The renewal of the steadfast and solid spirit (רוח נכון in v. 12a) and the upholding of the willing spirit רוח נדיבה סמך (in v. 14b) to provide the supplicant with support and strength, are metaphorically represented by the (re)building of the walls of Jerusalem: both walls and spirit will protect the city and the altar against dangers coming from the outside world. The central verse 13 and its word combination present the nucleus of it all: do not take away God's presence or his spirit of holiness from the midst of the Israelites. The renewal of a steadfast spirit and the upholding of a willing spirit are like the rebuilding of the city walls that will protect Jerusalem against incoming threats and impurities.

In sum, at the base of the second part of Psalm $5_{1}$ lies the metaphorical pattern of destruction and (re)construction, in which the heart is the contact point between the outside world and the inside world and in which the steadfast and sustaining spirit is metaphorically represented by the city walls. Because of the conceptual link of the steadfast spirit with the city walls, it might be suggested that the heart as the materialised point of access and departure metaphorically represents the city gate. If so, then two metaphors are active on the background of Ps 51:12-21, namely THE HEART IS THE CITY GATE and THE STEADFAST AND SUSTAINED SPIRIT IS THE CITY WALL. Only when the heart is purified and set apart again as a pure entity over and against the impure and defiling elements and only when the spirit is renewed and reinforced again, the Jerusalemites can re-use the altar again. 
This article focuses on the pivotal role of verses 12-14 in Psalm 51, on the meaning of their constituents, one of which is the verb ברא and on the standard translation of Ps 51:12 as "create for me a pure heart, o God". Central in this analysis stands v. 13, in which the speaker expresses the fear that due to his transgressions God's spirit of holiness will be taken away, because God does not tolerate impurity or un-holy behaviour of any kind. For the impurity generated by the transgressions will be projected onto the sanctuary, which in this way will be defiled. Therefore, aligned with רוח קדשך in v. 13 is טהור in v. 12: purity is the sine qua non for God's holy spirit to stay and keep active in the midst of the Israelites.

In this general setting three metaphorical patterns are distinguished: 1 . the metaphorical pattern of sin: SIN IS AN ACCOUNT / RESTORATION IS BLOTTING OUT THE ACCOUNT; SIN IS A STAIN / RESTORATION IS WASHING AWAY THE STAIN; SIN IS AN IMPURITY / RESTORATION IS PURIFICATION; SIN IS A PATH / RETURN FROM THIS PATH IS HOME-COMING TO GOD; 2. the metaphorical pattern of polity: GOD IS KING and GOD IS JUDGE; 3. the metaphorical pattern of destruction and construction: THE EFFECT OF SIN IS A STATE OF BROKENNESS/ FORGIVENESS IS RESTORATION AND RECONSTRUCTION and THE RENEWAL OF THE SPIRIT IS THE REBUILDING OF THE CITY WALLS.

The conclusion drawn is that Psalm $5^{1}$ is not a psalm of creation but one of sinfulness, forgiveness and restoration. The analysis of vv. 12-14 has demonstrated that the understanding of the notions of purity in v. 12 and of holiness in v. 13 are crucial for the Psalm. In the conceptual universe of purity and impurity it is not that the impure entity that is to be set apart, but the pure one. In fact, the impure world of words and deeds is the total from which the pure ones are to be separated. It is not the purity of the heart itself, but the process of purification that is expressed here, as the verbal clause in v. 12a shows. The verb ברא marks this act of separation or purification, so that "the ore remains" (as in metal refining): pure, cleared of sins. In fact the entire construction is in English best understood as "purification of the heart" and best translated as "purify for me a clean heart". 